\title{
Ruang Lingkup Hukum Dagang
}

\section{Sri Rezki}

\author{
Jurusan Perbankan Syariah Fakultas Eknomi Dan Bisnis Islam \\ Srireski@Gmail.Com
}

\begin{abstract}
Abstrak
Rahasia dagang sekarang ini sudah merupakan salah satu bentuk investasi yang mahal di samping bentuk investasi lain yang harus dijaga terhadap semua pihak agar tidak disalahgunakan untuk kepentingan pihak lain melalui satu mekanisme persaingan yang tidak jujur. Rahasia Dagang adalah informasi di bidang teknologi dan bisnis yang tidak diketahui oleh masyarakat, memiliki nilai ekonomis yang disebabkan oleh kegunaannya dalam kegiatan bisnis, dan dirahasiakan oleh pemilik Rahasia Dagang. Perlindungan hukum terhadap rahasia dagang dapat dipisahkan menjadi beberapa bagian, yaitu: 1 . Adanya unsur kontrak/perjanjian 2. Hak pemilik Rahasia Dagang diperhatikan (ada hak eksklusif) 3. Menampilkan perbuatan melawan hukum 4. Penyelesaian sengketa di pengadilan negara 5. Pengalihan hak rahasia dagang 6. Tidak ada jangka waktu perlindungan rahasia dagang. Bagaimana upaya pemilik rahasia dagang dalam mempertahankan keberadaan rahasia dagang untuk penyelesaian persaingan yang tidak sehat oleh pesaing dan tidak ada itikad baik, dan bagaimana bentuk penyelesaian konflik dalam pemecahan rahasia dagang. Sistem Perlindungan Rahasia Dagang memiliki cakupan yang lebih luas, karena di dalamnya terdapat ketentuan bahwa pembobolnya dapat dituntut secara perdata dan pidana. Pemberian perlindungan hukum atas rahasia dagang mempunyai arti penting, yaitu sebagai landasan bagi perlindungan yang efektif terhadap bentuk-bentuk informasi rahasia yang dikategorikan sebagai rahasia dagang dengan pengaturan pencegahan praktik persaingan tidak sehat yang dapat merugikan masyarakat. Disarankan perlindungan Undang-Undang Rahasia Dagang diatur lebih fokus karena Rahasia Dagang merupakan aset atau investasi yang bernilai tinggi dan mahal harganya bagi orang atau badan sebagai penemu Rahasia Dagang, oleh karena itu pemerintah membuat peraturan perundang-undangan untuk mengatur hal-hal tersebut. diperlukan terutama dalam melindungi aset yang bernilai ekonomi tinggi seperti Rahasia Dagang.
\end{abstract}

\section{Kata kunci : Dagang, investasi, ekonomi}




\section{Pengertian Hukum Dagang}

Kitab Undang-Undang Hukum Dagang (KUHD/Wetboek van Koophandel/WvK) tidak memberikan pengertian mengenai Hukum Dagang. Oleh karena itu, definisi hukum dagang sepenuhnya diserahkan pada pendapat atau doktrin dari para sarjana. Berikut adalah beberapa pendapat para sarjana mengenai pengertian hukum dagang: 1. Purwosutjipto Hukum Dagang adalah hukum perikatan yang timbul khusus dari lapangan perusahaan

2. R. Soekardono Hukum Dagang adalah bagian dari hukum perdata pada umumnya, yakni yang mengatur masalah perjanjian dan perikatan-perikatan yang diatur dalam Buku III Burgerlijke Wetboek (BW). Dengan kata lain, Hukum Dagang adalah himpunan peraturan-peraturan yang mengatur seseorang dengan orang lain dalam kegiatan perusahaan yang terutama terdapat dalam kodifikasi Kitab UndangUndang Hukum Dagang dan Kitab Undang-Undang Hukum Perdata. Hukum dagang dapat pula dirumuskan sebagai serangkaian kaidah yang mengatur tentang dunia usaha atau bisnis dan dalam lalu lintas perdagangan

3. Achmad Ichsan Hukum Dagang adalah hukum yang mengatur soal-soal perdagangan, yaitu soalsoal yang timbul karena tingkah laku manusia dalam perdagangan (marzuki, 2016) 
Dari beberapa pengertian tersebut diatas, maka dapat disimpulkan bahwa secara sederhana pengertian Hukum Dagang adalah keseluruhan aturan hukum yang berlaku dalam lalu lintas perdagangan atau dunia usaha yang bersumber dari aturan hukum yang telah dikodifikasikan maupun yang ada diluar kodifikasi. 


\section{Sejarah perdagangan di indonesia}

Sejak abad pertengahan eropa (1000/ 1500) yang terjadi di negara dan kota-kota di Eropa dan pada zaman itu di Italia dan Perancis selatan telah lahir kota-kota sebagai pusat perdagangan (Genoa, Florence, vennetia, Marseille, Barcelona dan Negaranegara lainnya )1 . Tetapi pada saat itu Hukum Romawi (corpus lurus civilis ) tidak dapat menyelsaikan perkara-perkara dalam perdagangan, maka dibuatlah hukum baru di samping Hukum Romawi yang berdiri sendiri pada abad ke-16 yang disebut hukum pedagang (koopmansrecht)2 . Karena bertambah pesatnya hubungan dagang maka pada abad ke-17 diadakan kodifikasi dalam hukum dagang oleh mentri keuangan dari raja Louis XIV (1613- 1715) yaitu Corbert dengan peraturan (Ordonnance Du Commerce) 1673. Dan pada tahun 1681 disusun Ordonnance De La Marine yang mengatur tenteng kedaulatan dan pada tahun 1807 di Perancis di buat hukum dagang tersendiri dari hukum sipil yang ada yaitu (Code De Commerce) yang tersusun dari Ordonnance Du Commerce (1673) dan Ordonnance Du La Marine (1838)3 . Pada saat itu Nederlands menginginkan adanya hukum dagang tersendiri yaitu KUHD belanda dan pada tahun 1819 drencanakan dalam KUHD ini ada 3 kitab dan tidak mengenal peradilan khusus. Lalu pada tahun 1838 akhirnya di sahkan. KUHD Belanda berdasarkan azas konkordansi

(ihsan, 2016) 


\section{Tujuan dan fungsi hukum perdagangan}

Hukum bisnis dibuat untuk mengatur dan melindungi bisnis dari berbagai risiko yang mungkin terjadi di kemudian hari. Di bawah ini adalah beberapa tujuan hukum bisnis yang perlu Anda ketahui:

1. Menjamin berfungsinya keamanan mekanisme pasar secara efisien dan lancar.

2. Melindungi berbagai suatu jenis usaha, khususnya untuk jenis Usaha Kecil Menengah (UKM).

3. Membantu memperbaiki sistem keuangan dan perbankan.

4. Memberikan perlindungan terhadap suatu pelaku ekonomi atau pelaku bisnis.

5. Mewujudkan bisnis yang aman dan adil untuk semua pelaku bisnis.

Seperti yang Anda ketahui, hukum dibuat untuk menciptakan kehidupan yang aman, tertib, dan tentram, sama dengan hukum bisnis. Di bawah ini beberapa fungsi hukum bisnis:

1. Menjadi sumber informasi yang bermanfaat bagi pelaku bisnis.

2. Pelaku bisnis dapat lebih mengetahui hak dan kewajbannya saat mambangun bisnis, sehingga bisnisnya tidak menyimpang dari aturan yang ada dan telah tertulis dalam Undang-Undang. 
3. Pelaku bisnis lebih memahami suatu hak-hak dan kewajibannya dalam suatu kegiatan bisnis (jalal, 2016)

4. Terwujudnya sikap dan perilaku bisnis atau kegiatan bisnis yang adil, jujur, wajar, sehat, dinamis, dan berkeadilan karena telah memiliki kepastian hukum. 


\section{Ruang Lingkup Hukum Dagang}

Peraturan hukum dagang meliputi berbagai unsur yang melibatkan perantaraan produsen dan konsumen. Berikut ruang lingkup hukum dagang.

Kontrak Bisnis

Jual beli

Hak atas kekayaan intelektual

Merger dan akuisisi

Bentuk-bentuk perusahaan

Penanaman modal asing

Perusahaan go public dan pasar modal

Perkreditan dan pembiayaan

Jaminan hutang

Surat berharga

Perlindungan konsumen

Asuransi

Keagenan dan distribusi

Perpajakan

Bisnis internasional 


\author{
Hukum pengangkutan (darat, laut, udara, dan multimoda) \\ Penyelesaian sengketa bisnis \\ Anti monopoli \\ Perburuan \\ - Pekerjaan orang perantara (makelar, komisioner, pedagang, dan sebagainya) \\ (fauzi, 2018)
}

\title{
Instrumen hukum perdagangan
}

Sumber-sumber hukum dagang ialah tempat dimana bisa didapatkan peraturanperaturan mengenai Hukum Dagang. Beberapa sumber Hukum Dagang yakni sebagai berikut ;
1. Kitab Undang-Undang Hukum Pidana (KUHD) KUHD mengatur berbagai perikatan yang berkaitan dengan perkembangan lapangan hukum perusahaan. Sebagai peraturan yang sudah terkodifikasi, KUHD masih terdapat kekurangan dimana kekurangan tersebut diatur dengan sebuah peraturan perundang-undangan yang lain.




\section{Kitab Undang-Undang Hukum Perdata (KUH Perdata)}

Sesuai pasal 1 KUHD, KUH Perdata menjadi sumber hukum dagang sepanjang KUHD tidak mengatur hal-hal tertentu dan hal-hal tertentu tersebut diatur dalam KUH Perdata khususnya buku III. Dapat dikatakan bahwa KUH Perdata mengatur sebuah pemeriksaan secara umum atau untuk orang-orang pada umumnya. Sedangkan KUHD lebih bersifat khusus yang ditujukan untuk kepentingan pedagang. (edward, 2016)

3. Peraturan

Perundang-Undangan

Selain KUHD, masih terdapat beberapa peraturan perundang-undangan lain yang mengatur Hukum Dagang, diantaranya yaitu sebagai berikut :

- UU No 10 Tahun 1998 tentang Perbankan

- UU No 1 Tahun 1995 tentang Perseroan Terbatas (PT)

- UU No 7 Tahun 1987 tentang Hak Cipta

- UU No 5 Tahun 1999 tentang Persaingan Usaha 
- UU No 8 Tahun 1995 tentang Pasar Modal

\section{Kebiasaan}

Kebiasaan yang dilakukan secara terus menerus dan tidak terputus dan sudah diterima oleh masyarakat pada umumnya serta pedagang pada khususnya, bisa digunakn juga sebagai sumber hukum pada Hukum Dagang. Hal ini sesuai dengan pasal 1339 KUH Perdata bahwa perjanjian tidak saja mengikat yang secara tegas diperjanjikan, tetapi juga terikat pada kebiasaan-kebiasaan yang sesuai dengan perjanjian tersebut. Contohnya tentang pemberian komisi, jual beli dengan angsuran, dan lain sebagainya.

\section{Perjanjian yang dibuat parak}

Berdasarkan pasal 1338 KUH Perdata disebutkan perjanjian yang dibuat secara sah berlaku sebagai undang-undang bagi mereka yang membuatnya. Dalam hal ini, persetujuan, perjanjian ataupun kesepakatan memegang peranan bagi para pihak. Contohnya yaitu dalam pasal 1477 KUH Perdata yang menentukan bahwa selama tidak diperjanjikan lain, maka penyerahan terjadi di tempat dimana barang berada pada saat terjadi kata sepakat. Misalkan penyerahan barang diperjanjikan dengan 
klausula FOB (Free On Board) maka penyerahan barang dilaksanakan ketika barang sudah berada di atas kapal.

6.

Perjanjian internasional diadakan dengan tujuan supaya pengaturan tentang persoalan Hukum Dagang bisa diatur secara seragam oleh masing-masing hukum nasional dari negara-negara peserta yang terikat dalam perjanjian internasional tersebut 


\section{DAFTAR PUSTAKA}

edward. (2016). instrumen hukum di indonesia. jurnal hukum dagang, 4(2), 11-23.

fauzi, a. (2018). konsep perdagangan di indonesia. jurnal ekonomi, 4(2), 22-43.

ihsan, a. (2016). perdagangan di islam. jurnal ekonomi , 3(2), 34-56.

jalal, a. (2016). perdagagan dalam konsep islam. jurnal perdagangan , 2(4), 32-54.

marzuki, i. (2016). konsep perdagangan. jurnal ekonomi, 4(2), 45-65. 